\title{
PELATIHAN KETERAMPILAN OLAHRAGA, KETERAMPILAN MEMBUAT STRAP MASKER, DAN PENYULUHAN KEBERSIHAN LINGKUNGAN SEKOLAH
}

\author{
Siti Napfiah ${ }^{1)}$, Nok Izatul Yazidah ${ }^{2)}$, Dian Fitri Argarini ${ }^{3)}$, Dean Abner ${ }^{4)}$ \\ IKIP Budi Utomo \\ ${ }^{1)}$ napfiahsiti@gmail.com,${ }^{2}$ izatulyazidah@gmail.com,${ }^{3}$ kejora.subuh14@gmail.com,${ }^{4)}$ deanabner30@gmail.com
}

\begin{abstract}
This PMBP activity aims to increase the interest and knowledge of students or the public in doing sports with good and correct techniques, Increase awareness of students or the public to store masks in a clean and safe place when not worn or not advised to wear a mask on the chin, and Increase students' awareness of the importance of maintaining the cleanliness of the school environment at SD Kristen Brawijaya 1 Malang. The method used in the implementation of PMBP is in the form of counseling methods, training, and question and answer tones. The activity began with observation at SD Kristen Brawijaya 1 Malang. Followed by core activities in the form of Sports Skills Training, Mask Strap Making Skills Training, and School Environment Hygiene Counseling. The target in this PMBP activity is the students of SD Kristen Brawijaya 1 Malang. The result of the implementation of PMBP at SD Kristen Brawijaya I Malang is: Students are able to practice basic techniques in sports that have been taught, students are able to answer questions related to sports techniques performed, when asked questions after activities,, Many students already have the awareness to put masks in a clean and safe place. As well as not wearing masks in dagu, students have begun to have an awareness of the cleanliness of the school environment, judging by the enthusiasm of students in carrying out mutual assistance. From the discussion above can be said to be successful, because from the observations after the training activities there is a better change. But there is still a slight drawback, there are still some students who have to be reminded not to wear masks on the chin. Perhaps in the upcoming activities will be given more understanding for how to wear a mask properly and properly.
\end{abstract}

Keywords: Olahraga, strap masker, kebersihan

\section{ANALISIS SITUASI}

Kelurahan Kauman merupakan kelurahan yang terletak di wilayah Kecamatan Klojen, Kota Malang. Kelurahan ini terdiri dari 10 RW (Rukun Warga) dan 67 RT (Rukun Tetangga). Secara administratif, Kelurahan Kauman dikelilingin oleh kelurahan lainnya yang ada di Kota Malang. Di sebelah utara, Kelurahan Kauman berbatasan langsung dengan Kelurahan Orooro Dowo, Kecamatan Klojen. Sedangkan di sebelah timur, kelurahan ini berbatasan langsung dengan Kelurahan Kidul Dalem, Kecamatan Klojen. Sementara di sebelah selatan, Kelurahan Kauman berbatasan dengan Kelurahan Kasin, Kecamatan Klojen. Lalu, di sebelah barat, kelurahan ini berbatasan dengan Kelurahan Bareng, Kecamatan Klojen.

Kelurahan Kauma mendukung misi Kota Malang sebagai salah satu kota pendidikan di Jawa Timur, pendidikan dari tingkat dasar, menengah pertama, hingga menengah atas hingga perguruan tinggi. Di kelurahan ini terdapat lima Sekolah Dasar, dua Madrasah Ibtidaiyah, dua Sekolah Menengah Pertama, satu Madrasah Tsanawiyah, dua Sekolah Menangah Atas, tiga Madrasah Aliyah, dan satu kampus, yakni IKIP Budi Utomo. Salah satu sarana pendidikan yang ada di kelurahan kauman adalah SD Kristen Brawijaya 1 Malang.

Masyarakat menyambut positif kegiatan gotong royong kerjabakti membersihkan lingkungan.Masyarakat sangat kompak dan bersemangat mengikuti gotong royong, (Yayang Alif Panjaya , 2014). Kegiatan Kerja Bakti Dusun, seluruh masyarakat yang berpartisipasisangat antusias dan kegiatan berjalan lancar hingga akhir kegiatan. Walaupun memiliki hambatan dimana perlatan kurang memadai, sehingga 
kerja bakti kurang maksimal. Namun dengan memanfaatkan peralatan yang ada dan kantong sampah untuk memungut sampah, (Arif Rahmanto, 2015). Program pembinaan olahraga lapangan berjalan dengan lancar (Lilis Sukmawati, 2014). Program kerjabakti, jalan sehat, senam lansia, pelatihan menghias toples dari kain flanel, membuat gantungan kunci dari kain flanel, hasta karya, pelatihan microsoft word, dan pelatihan membuat lampion dari benang berjalan dengan baik dan lancar. Peran dan animo masyarakat yang baik membantu terlaksananya program KKN (Darmawan Nashrullah, 2015). Kegiatan memberishkan lingkungan, dan pentas seni dan olahraga berjalan dengan baik dibuktikan dengan antusiasme masyarakat desa pada pelaksanaan kegiatan (Risna Podungge, 2020).

Permasalahan yang ada di SD Kristen Brawijaya 1 Malang ialah kurangnya minat dan pengetahuan siswa atau masyarakat dalam melakukan olahraga dengan teknik yang baik dan benar, kurangnya kesadaran siswa atau masyarakat untuk menyimpan masker di tempat yang bersih dan aman ketika tidak dipakai atau tidak disarankan memakai masker di dagu, dan kurangnya kesadaran siswa akan menjaga kebersihan lingkungan sekolah selama pandemi Covid-19.

Solusi yang ditawarkan ialah meningkatkan minat dan pengetahuan siswa atau masyarakat dalam melakukan olahraga dengan teknik yang baik dan benar, meningkatkan kesadaran siswa atau masyarakat untuk menyimpan masker di tempat yang bersih dan aman ketika tidak dipakai atau tidak disarankan memakai masker di dagu, dan meningkatkan kesadaran siswa akan pentingnya menjaga kebersihan lingkungan sekolah.

Tujuan dilaksanakan PMBP ini adalah dapat menambah pengetahuan dan keterampilan siswa atau masyarakat dalam melakukan olahraga dengan teknik yang baik dan benar, dapat menambah pengetahuan siswa atau masyarakat dalam menyimpan masker yang baik dan benar, dan dapat meningkatkan kesadaran siswa akan pentingnya menjaga kebersihan lingkungan sekolah.

\section{METODE PELAKSANAAN}

Metode yang digunakan dalam pelaksanaan PMBP ini berupa metode penyuluhan, pelatihan, dan tanya jawab. Adapun kegiatan ini dimulai dengan observasi di SD Kristen Brawijaya 1 Malang. Dilanjutkan dengan kegiatan inti berupa Pelatihan Keterampilan Olahraga, Pelatihan Keterampilan Membuat Strap Masker, dan Penyuluhan Kebersihan Lingkungan Sekolah. Adapun sasaran dalam kegiatan PMBP ini adalah siswa - siswi SD Kristen Brawijaya 1 Malang. Pengabdian ini dialksanakan selama tiga bulan.

\section{HASIL DAN PEMBAHASAN}

Hasil dari pelatihan keterampilan olahraga yaitu siswa mampu mempraktekkan teknik dasar dalam olahraga yang telah diajarkan, dan siswa mampu menjawab pertanyaan terkait teknik olahraga yang dilakukan, ketika diberi pertanyaan seusai kegiatan.

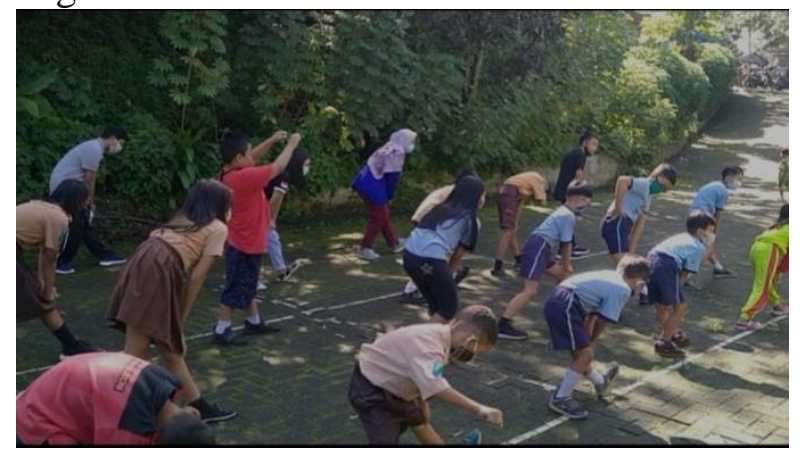

Gambar 1. Pelatihan Keterampilan Olahraga

Hasil dari pelatihan keterampilan membuat strap masker yakni, banyak siswa yang sudah memiliki kesadaran untuk menympan masker di tempat yang bersih dan aman. Serta tidak memakai masker di dagu. 


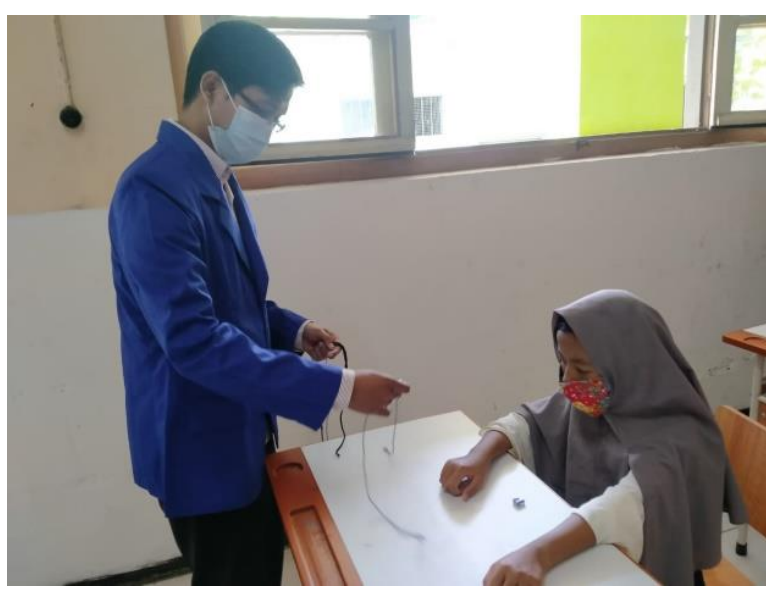

Gambar 2. Pelatihan Keterampilan Membuat Strap Masker

Sedangkan dari Penyuluhan Kebersihan Lingkungan Sekolah adalah siswa sudah mulai memiliki kesadaran akan kebersihan lingkungan sekolah, dilihat dari antusiasme siswa dalam melaksanan gotong royong.

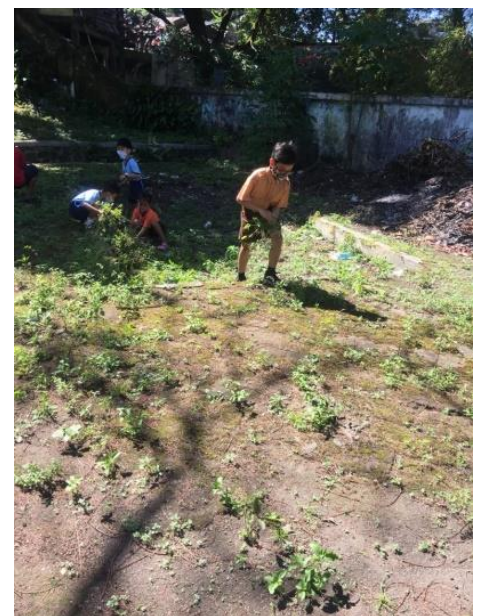

Gambar 3. Penyuluhan Kebersihan Lingkungan Sekolah

\section{KESIMPULAN}

Dari pembahasan di atas dapat dikatakan berhasil, karena dari hasil pengamatan setelah dilakukan kegiatan pelatihan terjadi adanya perubahan yang lebih baik. Namun masih ada sedikit kelemahan, masih ada beberapa siswa yang harus diingatkan untuk tidak memakai masker di dagu. Mungkin di kegiatan yang akan datang akan diberikan pemahaman lebih untuk cara memakai masker dengan baik dan benar.

Kegiatan pengabdian seperti ini dapat dilakukan secara rutin baik di lokasi yang sama maupun di lokasi yang berbeda dengan sasaran masyarakat yang benar - benar membutuhkan terutama mengenai olahraga dan kesadaran memakai masker yang baik dan benar.

\section{Ucapan Terima Kasih (jika ada)}

Ucapan terima kasih ditujukan kepada kepala SD Kristen Brawijaya 1 Malang, dewan guru SD Kristen Brawijaya 1 Malang, segenap civitas SD Kristen Brawijaya 1 Malang, serta seluruh siswa - siswi SD Kristen Brawijaya 1 Malang, dan rekan rekan Mahasiswa IKIP Budi Utomo yang telah membantu dalam pelaksanaan PMBP di SD Kristen Brawijaya 1 Malang.

\section{DAFTAR PUSTAKA}

Panjaya, Y. (2014). Pos Pemberdayaan Masyarakat (POSDAYA) Slaikers Desa Tratemulyo Kecamatan Weleri, Kabupaten Kendal di https://kkn.unnes.ac.id/lapkkn (akses 10 Mei 2021)

Rahmanto, A. (2015). Laporan KKN Dusun Sambeng III, Desa Poncosari, Kecamatan Srandakan, Kabupaten Bantul Yogyakarta di http://eprints.uny.ac.id (akses 10 Mei 2021)

Sukmawati, L (2014). KKN Universitas Pasir Pengairan Desa Lubuk Kerapat Kecamatan Rambah Hilir, Kabupaten Rokan Hulu, Provinsi Riau di https://upp.ac.id (akses 10 Mei 2021)

Nashrullah, dkk. (2015). Laporan Kelompok Kuliah Kerja Nyata (Kkn) Kelompok 24 Dusun Jatimulyo $R w$ 02, Kelurahan Kricak, Kecamatan Tegalrejo, Kota Yogyakarta Daerah Istimewa Yogyakarta di http://eprints.uny.ac.id (akses 10 Mei 2021)

Podungge, Risna, Aydalina. (2020). Pemberdayaan Masyarakat Pesisir 


\begin{abstract}
dalam Pengolahan Ikan Bandeng sebagai Bahan Pangan Kaya Nutrisi di Masa Pandemi Covid-19 Desa Trikora Kecamatan Popayato Kabupaten Pohuwato di htpps://repository.ung.ac.id (akses 10 Mei 2021)
\end{abstract}

